\title{
Isolation and characterization of Bradh1 gene encoding alcohol dehydrogenase from Chinese cabbage (Brassica rapa)
}

\author{
Sailila E. Abdula $\cdot$ Hye-Jung Lee $\cdot$ Reneeliza J. Melgar $\cdot$ Mingmao Sun $\cdot$ Kwon-Kyoo Kang $\cdot$ Yong-Gu Cho
}

Received: 15 March 2011 / Accepted: 20 March 2011

(c) Korean Society for Plant Biotechnology

\begin{abstract}
Alcohol dehydrogenase (E.C.1.1.1.1) is an enzyme present in higher plants involved in the anaerobic fermentation pathway that catalyzes the reduction of pyruvate to ethanol, resulting in continuous $\mathrm{NAD}^{+}$regeneration. It also plays an important role in many plant developments including tolerance to anoxia condition. Here, a cDNA clone encoding alcohol dehydrogenase (ADH) was isolated from Chinese cabbage (Brassica rapa) seedlings. The gene named Bradhl had a total length of 1,326 bp that contains a single open reading frame of $1,140 \mathrm{bp}$. The predicted protein consists of 379 amino acid residues with a calculated molecular mass of $41.17 \mathrm{kDa}$. Expression pattern analysis revealed a tissue-specific expressing gene in different tissues and strongly expressed in the shoot, roots and seeds of Chinese cabbage. Agrobacterium transformation of full-length cDNA Bradhl into rice Gopumbyeo showed high efficiency. Furthermore, induction of ADH in transgenic rice enhanced tolerance to anaerobiosis stresses and elevated mRNA transcripts. The overexpression of Bradh1 in rice increases germination under anaerobiosis stresses, implying the possibility of developing new varieties suited for direct seeding or flood-prone rice field.
\end{abstract}

Keywords alcohol dehydrogenase, ADH, Bradh1, transgenic rice, anaerobiosis, germination

\section{Introduction}

Rice plant is constantly challenged by environmental

S. E. Abdula, H.-J. Lee, R. J. Melgar, M. Sun, Y.-G. Cho ( $ه)$ Department of Crop Science, Chungbuk National University, Republic of Korea

e-mail: ygcho@cbnu.ac.kr

K.-K. Kang

Department of Horticulture, Hankyong National University, Republic of Korea stresses that reduce crop yield. With climate change, floods are highly unpredictable and may occur at any growth stage of the crop. Rice can tolerate some submergence as paddy rice or deep water rice. It is well adapted to flooding of the roots because of its ability to transport oxygen efficiently from the aerial parts of the plant to the roots. However, problems occur when the rice plant is completely submerged for periods of time (Drew 1997; Quimio et al. 2000). In direct seeding method of rice planting, poor establishment has been observed if the field is flooded during germination and early seedling development. Anaerobiosis, or the limitation of oxygen, is one of the better characterized environmental stresses endured during flooding. Rice rapidly dies when oxygen availability is limited (Voesenek et al. 2006). Gases diffuse 10,000 times slower in water than in air. Hence growth and survival during submergence of rice is affected by partial (hypoxia) or complete loss (anoxia) of $\mathrm{O}_{2}$. Reduced supply of $\mathrm{O}_{2}$ and $\mathrm{CO}_{2}$ as well as reduced $\mathrm{C}_{2} \mathrm{H}_{4}$ diffusion limit respiratory activities, photosynthesis and have a negative impact on elongation and growth of rice plants.

Alcohol dehydrogenase (ADH) (E.C.1.1.1.1) is an enzyme present in higher plants including Arabidopsis (Chang et al. 1986), barley, maize, pea, pearl millet, sunflower and wheat (Gottlieb 1982) and some prokaryotic organisms. ADH activity is considered essential for the survival of plants during anaerobic conditions (Johnson et al. 1994). Under normal aerobic environments carbohydrates in root cells is catabolized to carbon dioxide and water through glycolysis, the TCA cycle and oxidative phosphorylation. This process provides energy in the form of ATP (36 mole ATP per mole glucose). Under limiting oxygen concentrations, root cells switch from aerobic to anaerobic metabolism, the majority of pyruvate undergoing alcoholic fermentation generating $\mathrm{NAD}^{+}$and a limited amount of ATP (2 mole ATP per mole glu- 
cose) (Roberts et al. 1984). Alcoholic fermentation consists of two steps catalyzed by pyruvate decarboxylase and alcohol dehydrogenase, these enzymes converting pyruvate through a toxic intermediate, acetaldehyde, into ethanol.

$\mathrm{ADH}$ expression is tissue specific. In general, expression of the adh gene has been shown predominantly in roots, as well as seeds (cotyledon and primary root) and pollen, while lacking in green aerial tissues of most plant species (Freeling and Bennett 1985; Dolferus et al. 2003). It has been shown that ADH mRNA level increases with anaerobiosis. This indicates that the ADH enzyme is regulated at the transcriptional level (Xie and Wu, 1989; Lasanthi- Kudahettige et al. 2007). More, its expression is also increased in response to dehydration, low temperatures and to abscisic acid and it plays an important role in many plant developments (Thompson, et al. 2010). Recently, several studies have focused on the effect of overexpression of genes on flooding tolerance. Zhang et al. (2000) overexpressed a gene involved in cytokinin biosynthesis and demonstrated improved flooding tolerance in Arabidopsis. Grichko and Glick (2001) overexpressed a bacterial ACC deaminase under the control of three different promoters and were able to produce transgenic tomato (Lycopersicon esculentum) plants that had increased flooding tolerance. Pathhuri (2011) reported that alcohol dehydrogenase 1 of barley modulates susceptibility to the parasitic fungus Blumeria graminis f.sp. hordei.

The importance of $\mathrm{ADH}$ for the germination of seeds under anaerobic circumstances is illustrated by $a d h l$ null mutants which lack ADH activity. These mutants fail to germinate after prolonged periods of hypoxia, whereas wild type, ADH-producing plants, germinates under these conditions. Plants which are more flooding tolerant have a more active alcoholic fermentation pathway and $a d h 1$ null mutants are more flooding sensitive (Kennedy et al. 1992; Roberts et al. 1984). Engineering varieties with tolerance to anoxia stress is very important for direct seeding of crop establishment. Here, we isolated and reported the transformation of the full-length cDNA Bradhl gene derived from Chinese cabbage (Brassica rapa) and compared its overexpression in rice against anoxia condition.

\section{Materials and methods}

Isolation and cloning of Bradh1 gene

Total RNA was extracted from Chinese cabbage (Brassica rapa) with easy-BLUE reagents (iNtRON Biotechnology, Seoul, Korea). For reverse transcription-PCR (RT-PCR), 1 ug of total RNA was treated with RNase-free DNase and first-strand cDNA was synthesized using an oligo (dT) primer (Invitrogen, Carlsbad, CA, USA). This cDNA was used as a template for PCR amplification with degenerate primers of 5'-ATGTCTACCACCGGACAG AT-3' (BR11-Fw) and 5'-TCAAGCACCCATGGTGAT G-3' (BR11-Rv). PCR condition was the followings: denaturation at $94^{\circ} \mathrm{C}$ for $5 \mathrm{~min}$, followed by 35 sequential cycles of $94^{\circ} \mathrm{C}$ for $40 \mathrm{sec}, 55^{\circ} \mathrm{C}$ for $40 \mathrm{sec}, 72^{\circ} \mathrm{C}$ for $2 \mathrm{~min}$, and an extension at $72^{\circ} \mathrm{C}$ for $10 \mathrm{~min}$. The RT-PCR products were electrophoresed and visualized on a $1.0 \%(\mathrm{w} / \mathrm{v})$ agarose gel with ethidium bromide (EtBr). The PCR products were subsequently cloned into a pGEM T-Easy vector (Promega), and sequenced extensively. On the basis of this cloned fragment of Bradh1 cDNA, the RACE approach was then employed to amplify the 3' and 5' ends of Bradh1 cDNA using 5' and 3' RACE kit (TaKaRa, Shiga, Japan). All the inserted sequences were checked for their homology using the BLAST program in NCBI sequence database and another program in the GenBank/EMBL/DDBJ sequence database.

\section{Vector construction and transformation of Bradh1}

The Bradhl full length cDNA was ligated into the pBig sfiI vector (TaKaRa, Shiga, Japan). The recombinant vector with Bradhl has been constructed under the control of CaMV 35S promoter and NOS terminator as shown in Figure 1 and transformed using Agrobacterium tumefaciens-mediated transformation method.

\section{Production of Bradhl transgenic plants}

The transformation was carried out according to the method of Toki et al. (2006) with some modifications. Mature rice seeds of japonica rice cultivar Gopumbyeo were dehulled and sterilized with $70 \%$ ethanol for 1 min prior to washing in sterile water. Seeds were further sterilized with $2.5 \%$ sodium hypochlorite containing one drop of Tween 20 per $50 \mathrm{ml}$ for $15 \mathrm{~min}$ then washed five times in sterile water. This step was repeated once without Tween 20. The sterilized seeds were inoculated on N6D medium solidified with $0.4 \%$ Gelrite and cultured under continuous light at $32^{\circ} \mathrm{C}$ for 5 days.

Agrobacterium strain EHA105 harboring binary Ti plasmid $p F L C I I I$ (Fig. 1) containing the full-length cDNA of alcohol dehydrogenase gene was cultured on $\mathrm{AB}$ 


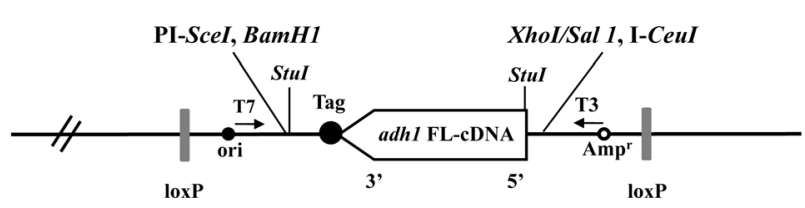

Fig. 1 Schematic diagram of the binary Ti plasmid $p F L C I I I$ containing the alcohol dehydrogenase full-length cDNA from Brassica rapa

medium containing $50 \mathrm{mg} / \mathrm{L}$ kanamycin sulfate solidified with $1.5 \%$ agar for 3 days at $28^{\circ} \mathrm{C}$ in the dark. Agrobacterium culture was scraped from the plates and suspended in AAM medium to yield an $\mathrm{OD}_{600}$ of approximately 0.3. Pre-cultured seeds were immersed in the Agrobacterium suspension by gently inverting the tube for $1.5 \mathrm{~min}$, blotted dry with a sterilized filter paper to remove excess bacteria. The seeds were transferred onto a sterilized filter paper that had been moistened with $0.5 \mathrm{ml}$ of AAM medium placed on 2N6-AS medium solidified with $0.4 \%$ Gelrite.

After 3 days of co-cultivation at $25^{\circ} \mathrm{C}$ in the dark, seeds were washed five times in sterilized water and then washed once in sterilized water containing 500 $\mathrm{mg} / \mathrm{L}$ carbenicillin to remove Agrobacterium. The seeds were rapidly blotted dry on a sterilized filter paper and cultured on N6D medium containing $50 \mathrm{mg} / \mathrm{L}$ hygromycin and $400 \mathrm{mg} / \mathrm{L}$ carbenicillin under continuous light at $32^{\circ} \mathrm{C}$ for 2 weeks. Proliferating calli arising from the scutellum were transferred to RE-III medium. Plantlets arising from the calli were transferred to HF medium to induce roots.

DNA extraction and PCR analysis

Genomic DNA was extracted as described by Cho et al. (2007) with some modifications. $0.2 \mathrm{~g}$ of ground powder of fresh rice leaf tissue was placed in $2 \mathrm{ml}$ microcentrifuge tube, and $900 \mu \mathrm{l}$ of $65^{\circ} \mathrm{C}$ preheated extraction buffer $(\mathrm{pH} 7.8 \sim 8.0)$ was added. After incubation in waterbath at $65^{\circ} \mathrm{C}$ for $30 \mathrm{~min}, 700 \mu \mathrm{l}$ of phenol : chloroform : isoamyl alcohol (25:24:1) was added into the tube and mixed for $10 \mathrm{~min}$, and centrifugation was carried out at $13,000 \mathrm{rpm}$ for $10 \mathrm{~min}$. The upper phase was transferred into a new $2 \mathrm{ml}$ tube and equal volume of chloroform : isoamyl alcohol (24:1) was added and mixed for $10 \mathrm{~min}$. The mixed samples were centrifuged at $13,000 \mathrm{rpm}$ for $10 \mathrm{~min}$ and the upper phase was transferred into a new $1.5 \mathrm{ml}$ tube containing $4 \mu \mathrm{l}$ of $10 \mathrm{mg} / \mathrm{ml} \mathrm{RNase1.} \mathrm{After} \mathrm{incubation}$ at $37^{\circ} \mathrm{C}$ for $30 \mathrm{~min}, 0.7$ volume of pre-cooled isopropanol was added and mixed well, and centrifuged at
$13,000 \mathrm{rpm}$ at $4^{\circ} \mathrm{C}$ for $15 \mathrm{~min}$. The supernatant was discarded and $1 \mathrm{ml}$ of $70 \%$ ethanol was applied to wash the DNA pellet and centrifuged at $13,000 \mathrm{rpm}$ for 5 min. DNA pellet was air-dried and suspended in $50 \mu \mathrm{l}$ of double-distilled water. The relative purity and concentration of extracted DNA was estimated using NanoDrop-1000. PCR analysis was performed using HPTFw (GGA TTT CGG CTC CAA TGT CCT GAC GGA) and HPT-Rv (CTT CTA CAC AGC CAT CGG TCC AGA) primers to check the introgression of hygromycin phosphotransferase gene (hpt) and pBigs_ SfiI-Fw (TAT TCG GAG AGG GTA CGT ATT TTT AC) and pBigs_sfil-Rv (GCA ACA GGA TTC AAT CTT AAG AAA CT) to check the introgression of the full-length cDNA of alcohol dehydrogenase gene from $\mathrm{T}_{1}$ generations.

\section{Activity and expression of alcohol dehydrogenase}

Rice culture technique: Rice seeds were soaked in $1 \%$ sodium hypochlorite for $15 \mathrm{~min}$, washed with sterilized distilled water for 30 minutes until there are no more traces of sodium hypochlorite, and then soaked in sterile water. Seeds were germinated in the dark at $32^{\circ} \mathrm{C}$. Microbial contaminations were kept to a minimum by daily water changes. Six-day old etiolated rice seedlings were used for anaerobic induction, $\mathrm{ADH}$ activity assays and RNA experiments.

Anaerobic induction: Six-day old etiolated rice seedlings were induced by immersion in $10 \mathrm{mM}$ Tris- $\mathrm{HCl}(\mathrm{pH}$ 8.0) in flasks. Tris- $\mathrm{HCl}$ buffer was boiled to remove any air. When cooled, it was degassed using a vacuum pump and then bubbled with $\mathrm{N}_{2}$ gas continuously for $30 \mathrm{~min}$ to remove any air. The rice seedlings were quickly transferred into the flasks, which were wrapped with aluminum foil. $\mathrm{N}_{2}$ was again bubbled continuously into the buffer in the flasks for $10 \mathrm{~min}$. The flasks were then put into a degassed $\mathrm{N}_{2}$-filled sealed chamber.

ADH activity assay: After each twelve-hour period of anaerobic induction, the etiolated rice seedlings were taken out of the flasks, quickly frozen with liquid nitrogen and cut into shoot and roots, each part containing at least $0.5 \mathrm{mg}$ of fresh weight. Each part was separately ground with liquid nitrogen using mortar and pestle. After the liquid nitrogen has evaporated completely, 1 $\mathrm{ml} \mathrm{ADH}$ grinding buffer was added to the samples and mixed for $5 \mathrm{~min}$, and then centrifuged at $0^{\circ} \mathrm{C}$ for 15 min. The supernatant was transferred to a new $1.5 \mathrm{ml}$ tube. ADH enzyme activity was measured after the addition of $10 \mu \mathrm{l}$ or rice tissue extract and $400 \mu \mathrm{l}$ ADH 
reaction mixture. The activity was calculated from the linear portion of the curve during the accumulation of NADH. The protein concentration of the crude extracts was determined according to the Bradford Method using bovine serum albumin, fraction IV (Sigma) as the standard.

Anaerobic germination analysis: Seeds of transgenic rice $\mathrm{T}_{1}$ generation that was positive in both HPT and pBigs_SfiI primers were selected. They were surface sterilized with $50 \%(\mathrm{v} / \mathrm{v})$ commercial bleach for 15 min, followed by rinsing in sterile distilled water for 30 min. Seeds were then soaked in degassed sterile distilled water and supplied with $\mathrm{N}_{2}$ gas for $30 \mathrm{~min}$. They were carefully sealed in petri dishes and not allowing any $\mathrm{O}_{2}$ to come in. Seeds were then germinated in $32^{\circ} \mathrm{C}$. After 2 and 6 days, seedlings were removed from the petri dish, washed with distilled water and placed on moistened filter paper. Shoot length was measured in $\mathrm{mm}$. Survival was based on the ability of the plants to resume growth of the roots and greening of the shoots.

RNA extraction and $c$ DNA preparations

Total RNA was extracted from the leaf and root of each adh1 mutant lines and wild type gopumbyeo plant using the Easy-spin IIP kit (Cat. No.17310) according to the manufacturer's instructions. This process was repeated after 12, 24, 36, 48, 60, and 72 hour of anaerobic treatment. The relative purity and concentration of extracted RNA was estimated using NanoDrop1000 spectrophotometer (NanoDrop Technologies, Inc. USA), and stored at $-80^{\circ} \mathrm{C}$ freezer. Total RNAs were cleaned using DNase 1 kit (Cat. No: 18068-015, Invitrogen), and the first-strand cDNA synthesis was performed by reverse transcription of $m$ RNA using Oligo $(\mathrm{dT})_{20}$ primer and SuperScript ${ }^{\mathrm{TM}}$ III Reverse Transcriptase (Cat. No: 18080-051, Invitrogen). The specific sequences of the primer pairs used in a semi-quantitative reverse transcription PCR (RT-PCR) are BR 11-Fw (5'- ATT CTCCATCAACGGCAAAC -3') and BR 11-Rv (5'CCGAGACCGAAGATAGCAAC -3'). Actin primers were used as loading controls and also used as internal controls for normalization of quantitative RT-PCR reaction

\section{Results}

Cloning and sequence analysis of Bradh1 cDNA

To isolate Bradh1 from Chinese cabbage plants, the sequence search in the cDNA library of other related to $a d h$ sequences was performed using the database of NCBI nucleic acid sequence. The sequence degenerate primers of 5'-ATGTCTACCACCGGACAGAT-3' (BR11Fw) and 5'-TCAAGCACCCATGGTGATG-3' (BR11-Rv) were designed and used for cloning of a 1,326 bp cDNA that contains a single open reading frame of $1,140 \mathrm{bp}$ Brassica rapa adhlgene (Bradh1, JF682847) (Fig. 2). The predicted protein consists of 379 residues with a calculated molecular mass of $41.17 \mathrm{kDa}$. It was found out that high sequence similarity to Arabidopsis adh1 (NM106362.2)(Atadh1, 88\% on the nucleic acid level) and Brassica oleracea adh1 (AF110433.1) (Boadh1, 97\%) (Fig. 3). Sequence similarity to Oryza sativa adh1 (EF122490.1) (Osadh1) and Zea maize adh1 (NM0011 11939.1) (Zmadh1) is 76\%. Adh1 gene has been cloned and isolated in other crops. In Arabidopsis, the DNA sequence contains an open reading frame similar to the Bradh1 capable of encoding a polypeptide the same length as maize $a d h 1$ and adh2 (379 amino acids) and having $80 \%$ homology with both maize enzymes (Chang and Meyerowitz 1986).

Development of transgenic rice overexpressing Bradh1

Oryza sativa L. cv Gopumbyeo was transformed through

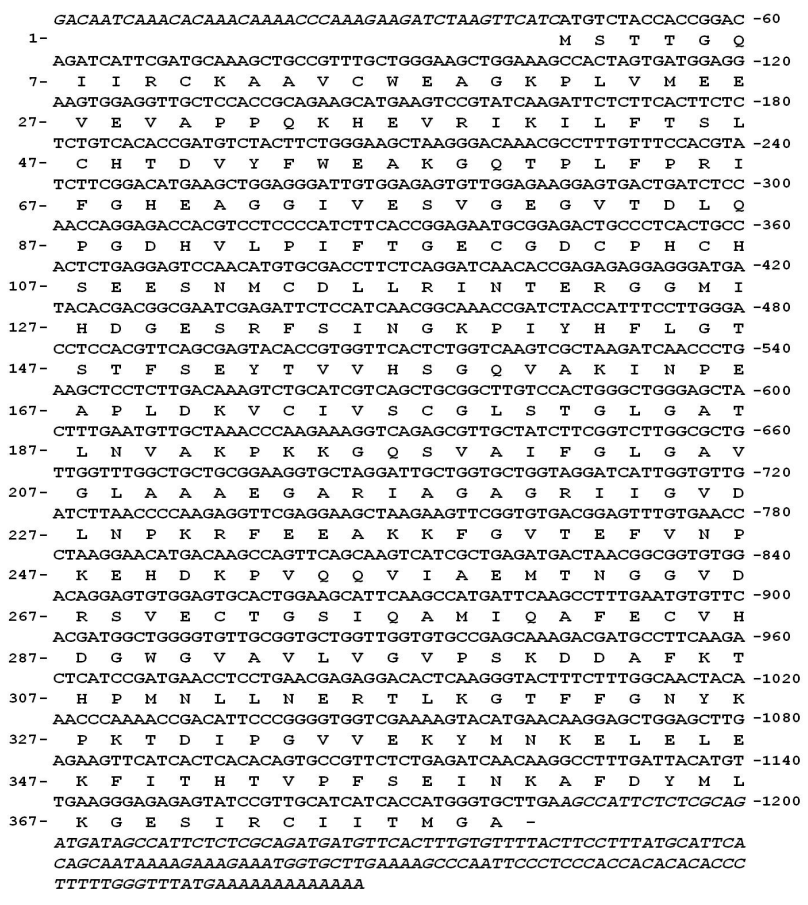

Fig. 2 Nucleotide and deduced amino acid sequences of a Bradh1 (JF682847) gene encoding alcohol dehydrogenase in Chinese cabbage (Brassica rapa) 


\begin{tabular}{|c|c|c|}
\hline \multirow{7}{*}{\multicolumn{2}{|c|}{$\begin{array}{l}\text { Zmadh1 } \\
\text { Bradh1 } \\
\text { Boadh1 } \\
\text { Atadh1 }\end{array}$}} & MATAGKVIKCKAAVAUEAAKPLVIEEVEVAPPQAMEVRVKILFTSLCHTDVYF WEAKGQT \\
\hline & & HATAGKVIKCKAAVAUEAGKPLSIEEVEVA--KEMEVRVKILFTSLCHTDVYF UEAKGQT \\
\hline & & ИATAGKVIKCKAAVAUEAGKPLS IEEVEVAPPQAMEVRVKILFTSLCHTDVYF WEAKGQT \\
\hline & & HSTTGQI IRCKAAVCUE AGKPLVMEEVEVAPPQKHEVRIKILFTSLCHTDVYF UE AKGQT \\
\hline & & USTTGQI IRCKA AVCUE AGKPLVIEEVEVAPPQKHEVRIKILFTSLCHTDVYF UE AKGQT \\
\hline & & USTTGQI IRCKAAVAUEAGKPLVIEEVEVAPPQKHEVRIKILFTSLCHTDVYF UEAKGQT \\
\hline & & 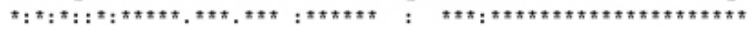 \\
\hline & Osadh1 (japonica) & PVFPRIFGHE AGGIVESVGEGVTDLAPGDHVLPVFTGECKECAHCKSAESNHCDLLRINT \\
\hline & Osadh1 (indica) & PVFPRIF GHEAGGIVESVGE GVTDLAPGDHVLPVFTGECKECAHCKSAESNMCDLLRINT \\
\hline & $2 \operatorname{madh} 1$ & PVFPRIFGHE AGGIIESVGEGVTDVAPGDHVLPVFTGECKECAHCKSAESNMCDLLRINT \\
\hline & Bradh1 & PLFPRIFGHE AGGIVESVGEGVTDLQPGDHVLPIFTGECGDCPHCHSEESNUCDLLRINT \\
\hline & Boadh1 & PLFPRIFGHE AGGIVESVGEGVTDLXPGDHVLPIFTGECGDCPHCHSEESNMCDLLRINT \\
\hline & Atadh1 & PLFPRIFGHE AGGIVESVGE GVTDLQPGDHVLP IFTGECGECRHCHSEESNMCDLLRINT \\
\hline & & 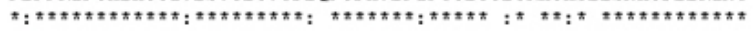 \\
\hline & Osadh1 (japonica) & DRGVMIGD GKSRF SINGKP IYHFVGTSTF SEYTVMHVGCVAKINP AAPLD KVCVLSCGIS \\
\hline & Osadh1 (indica) & DRGVMIGD GKSRFS INGKP I YHF IGTSTFSEYTVMHVGCVAKINP AAPL DKVCVLSCGIS \\
\hline & Zmadh1 & DRGVII ADGKSRF S INGKP I YHFVGTSTFSEYTVMHVGCV AKINPQAPL DKVCVLSCGYS \\
\hline & Bradh1 & ERGGMIHDGESRFS INGKP IYHF LGTSTFSEYTVVHSGQVAKINPEAPLDKVCIVSCGLS \\
\hline & Boadh1 & ERGGMIHDGESRFS INGKP IHHF LGTSTFSEYTVVHSGQVAKINPEAPLDKVCIVSCGLS \\
\hline & Atadh1 & ERGGMIHDGESRFS INGKP IYHFLGTSTFSEYTVVHSGQVAKINPD APLDKVCIVSCGLS \\
\hline & & 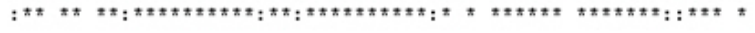 \\
\hline & Osadh1 (japonica) & TGLGATINVAKPPKGSTVAIFGLGAVGLAAAEGARIAGASRIIGIDLNANRFEEARKFGC \\
\hline & Osadh1 (indica) & TGLGATINVAKP-KGSTVAIFGLGAVGLAAAEGARIRGASRI IGIDLNANRFEEARKFGC \\
\hline & $2 \operatorname{madh} 1$ & TGLGAS INVAKPPKGSTVAVFGLGAVGLAAAEGARIAGASRI IGVDLNPSRFEEARKFGC \\
\hline & Bradh1 & TGLGATLNVAKPKKGQSVAIFGLGAVGLAAAEGARIAGAGRI IGVDLNPKRFEEAKKFGV \\
\hline & Boadh1 & TGLGATLNVAKPKKGQSVAIFGLGAVGLAAAEGARIAGAGRI IGVDLNPKRFEEAKKFGV \\
\hline & Atadh1 & TGLGATLNVAKPKKGQSVAIFGLGAVGLGAAEGARIAGASRI IGVDFNSKRFDQAKEFGV \\
\hline & & 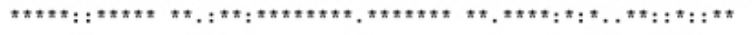 \\
\hline & Osadh1 (japonica) & TEFVNPKDHDKPVQQVL AEMTNGGVDRSVECTGNINAMIQAFECVHDGUGV AVLVGVPHK \\
\hline & Osadh1 (indica) & TEFVNPKDHD KPVQQVL AEMTNGGVDRSVECTGNINAMIQAFECVHDGUG I AVLVGVPHK \\
\hline & Zmadh1 & TEFVNPKD HNKPVQEVL AEMTNGGVDRSVECTGNINAMIQAFECVHDGUGVAVLVGVPHK \\
\hline & Bradh1 & TEFVNPKEHDKPVQQVIAEMTNGGVDRSVECTGSIQAMIQAFECVHDGUGVAVLVGVPSK \\
\hline & Boadh1 & TEFVNPKEHDKPVQEVIAEMTNGGVDRSVECTGSIQAMIQAFECVHDGUGV AVLVGVPSK \\
\hline & stadh1 & TECVNPKD HDKP IQQVI AENTDGGVDRSVECTGSVQAMIQAFECVHDGUGV AVLVGVPSK \\
\hline & & 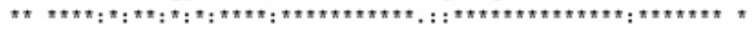 \\
\hline & Osadh1 (japonica) & D AEF KTHP MNF LNERTL KGTFF GNYKP RTDLPNVVEL YMKKELEVE KF I THSVPFSE INT \\
\hline & Osadh1 (indica) & DAEF KTHP RNF LNERTL KGTF F GNYKPRTDLPNVVEL YMKKELEVE KF ITHSVPFSE INT \\
\hline & $2 \operatorname{madh} 1$ & DAEF KTHP INNF LNERTL KGTF F GNYKPRTDLPNVVEL YMKKELEVEKF ITHSVPF AE INK \\
\hline & Bradh1 & DDAFKTHPMNLLNERTLKGTFF GNYKP KTD IPGVVEKYMNKELELEKF ITHTVPFSE INK \\
\hline & Boadh1 & DD AF KTHP MNL LNERTL KGTF FNYKP KTD IPGVVE KYMNKELELE KF ITHTVPFSE INK \\
\hline & stadh1 & DD AF KTHP MNF LNERTL KGTF F GNYKP KTD IPGVVEKYMNKELELEKF ITHTVPFSE INK \\
\hline & & " \\
\hline & Osadh1 (japonica) & AF DLMHKGEGIRCI IRMEN \\
\hline & Osadh1 (indica) | & AFDLMHKGEAIRCIIRMEN \\
\hline & $2 \operatorname{madh} 1$ & AFDLMAKGEGIRCIIRMEN \\
\hline & Bradh1 & AFDYHLKGESIRCIITMG\& \\
\hline & Boadh1 & AFDYMLKGESIRCIITMGA \\
\hline & Atadh1 & AFD YMLKGES IRCI I TMGA \\
\hline & & 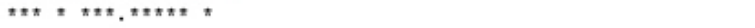 \\
\hline
\end{tabular}

(B)

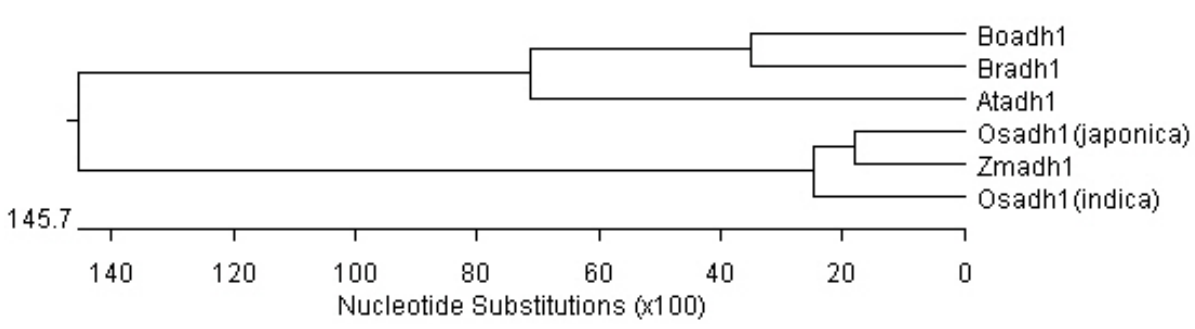

Fig. 3 Multiple alignment of deduced amino acid sequences of Bradhl with other related proteins and phylogenetic tree analysis. (A) Alignment of deduced amino acid sequences of Bradh1(JF682847) gene, Boadh1 (AF110433.1), Atadh1 (NM106362.2), Osadh1(japonica) (EF122490.1), Zmadh1 (NM001111939.1). Putative signal peptide and active site domain are shaded. (B) Phylogenetic tree of alcohol dehydrogenase genes by ClustalW. The numbers next to the nodes give bootstrap values from 100 replicates

Agrobacterium containing the full-length cDNA of alcohol dehydrogenase gene 1 from Brassica rapa. A total of 58 regenerated plants from co-cultivation of rice seeds were analyzed by PCR. Of the $58 \mathrm{~T}_{1}$ plants, $98 \%$ and $70 \%$ were positive with hpt and pBigs_sfl primers, respectively (Fig. 4). The size of the introduced full- length alcohol dehydrogenase cDNA is about $1 \mathrm{~kb}$. All of the amplified products for both $h p t$ and pBigs_SfiI primers were single bands. Here, our transformation efficiency is relatively high $(70 \%)$. The advantages of Agrobacterium-mediated transformation over other methods are high efficiency of transformation, the transfer of 
pieces with defined ends, the transfer of relatively large segments of DNA, and the absence of requirement protoplast-culture techniques. This method has demonstrated the stable integration of foreign DNA in rice chromosomes (Chan et al. 1993; Hiei et al. 1994).

\section{Expression level of Bradh1 gene}

In order to explain the expression pattern of the Bradh1 gene in the different organs, we performed an RT-PCR analysis on different parts of Brassica rapa plants using the pistil, stamen, bud, calyx, rachis, petal, leaf, shoot, root, and seed (Fig. 5). Bradh1 mRNA transcripts were detected in all organs, however, the highest levels were in shoot, root, and seed. In transgenic rice, Bradh1 mRNA transcript is highly expressed in root, followed

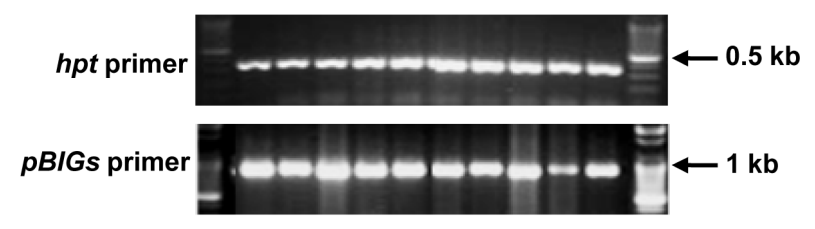

Fig. 4 Representative of genomic PCR analysis of transformants ( $\mathrm{T}_{1}$ generation). Upper level is the hpt (hygromycin resistant) and the lower level is pBigs_SfiI primers. PCR products were run in $1 \%$ agarose gel by electrophoresis. Bands were viewed using ethidium bromide under UV light

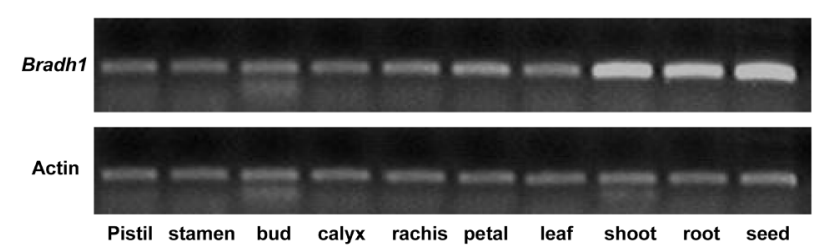

Fig. 5 Expression of Bradh1 gene in Brassica rapa. Upper panel shows expression level and lower panel shows internal actin used for loading adjustment

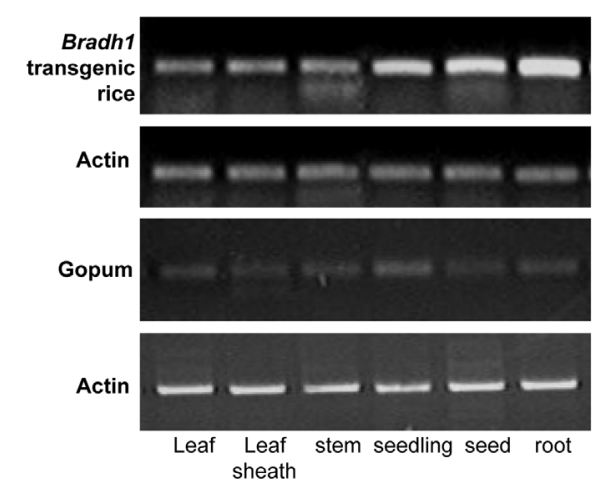

Fig. 6 Expression of Bradh1 gene in transgenic rice plants and wild type, Gopumbyeo by seed and seedlings (Fig. 6). The same expression pattern was observed in both Brassica rapa and transgenic rice. This result revealed that Bradhl gene is tissue specific and that mRNA transcript is highly regulated.

Bradh1 activity and expression under anaerobiosis

ADH activity was induced in Bradhl transgenic rice lines and wild type, Gopumbyeo. Six-day old etiolated rice seedlings were used for the anaerobic induction. The ADH activity for both transgenic rice lines and wild type were both increasing as the length of anaerobic induction increases. However, the transgenic rice lines showed higher $\mathrm{ADH}$ activity in both roots and shoots than wild type (Fig. 7, 8). Interestingly, significant differences in roots between mutants and wild type were observed after $48 \mathrm{hr}$ with t-test value of 2.17 indicating that Bradhl gene played an important role during

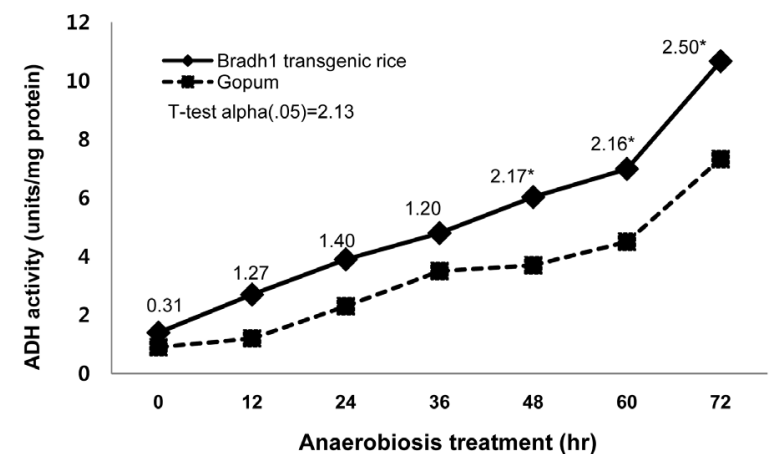

Fig. 7 Bradh 1 transgenic rice and Gopumbyeo ADH activity isolated from 6-day old roots under anaerobiosis. Units of $\mathrm{ADH}$ enzyme per mg protein were calculated from the increase of $\mathrm{NADH}$ during the assay. The numbers above the line indicates the t-test value. Asterisk $\left(^{*}\right)$ means significant at $\alpha(0.05)$

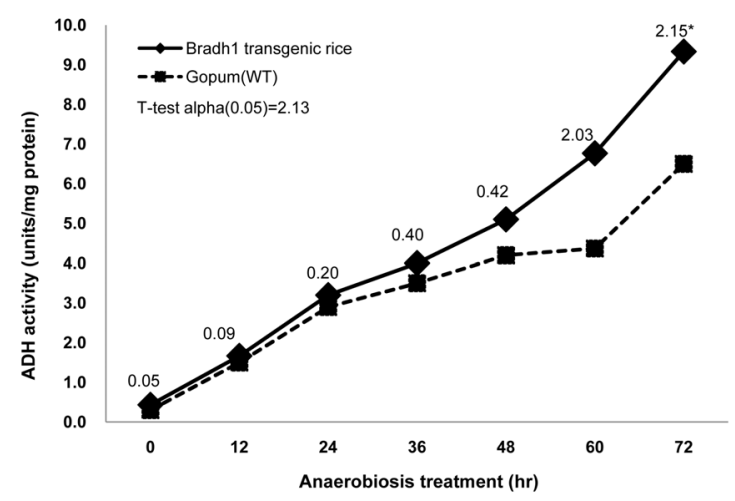

Fig. 8 Transgenic rice and Gopumbyeo ADH activity isolated from 6-day old etiolated shoots under anaerobiosis. Units of $\mathrm{ADH}$ enzyme per mg protein were calculated from the increase of NADH during the assay. The numbers above the line indicates the t-test value. Asterisk $(*)$ means significant at $a(0.05)$ 
anaerobiosis. Though the shoot increases overtime, significant differences were only observed after $72 \mathrm{hr}$ of anaerobiosis. Overall, shoots and roots showed an almost ten-fold increase in $\mathrm{ADH}$ activity compared to the basal level $(0 \mathrm{~h})$.

The induction of rice Bradh1 mRNA, as seen in the RT-PCR analysis (Fig. 9), correlated with the induction of ADH activity under anaerobiosis. RT-PCR analysis showed an increasing expression from $0 \mathrm{~h}$ of treatment up to $72 \mathrm{hr}$. The transgenic rice lines also showed over expression of the Bradhlgene under anaerobiosis as compared to wild type. This supports the data showing higher $\mathrm{ADH}$ activity in transgenic rice line than the wild type.

\section{Anaerobic germination analysis}

Pre-germinated seeds of transgenic rice and wild type, Gopumbyeo, were tested for survival under anoxia condition (Fig. 10). Results showed that rice can germinate in an anaerobic condition as manifested in the $100 \%$ survival after 2 day of anaerobic stress. However, after prolong period of anoxia ( 6 day) the transgenic rice lines have $6 \sim 8 \%$ higher seedling survival rates compared to wild type, Gopumbyeo. Throughout the anaerobic germination test, root growth was arrested and shoot growth was limited (data not shown). Most of the shoot growth took place in the second and fourth day but they continued to grow until the sixth day. Some of the transgenic rice lines exhibited longer shoots which suggests that transgenic rice line can adapt better to anaerobic conditions.

Rice is well-known example plant species capable of germinating under totally anaerobic conditions. It can germinate in anaerobic conditions presumably by using energy produced primarily through fermentative metabolism (Kennedy et al. 1992). When rice seeds are germinated in $\mathrm{N}_{2}$ or under water, only a shoot is produced. It is limited to coleoptiles extension (Turner et al. 1981; Atwell et al. 1982). The transgenic rice lines showed longer coleoptiles compared to the wild type. This data is in accordance with the RT-PCR analysis showing over expression of Bradhl in transgenic lines compared to wild type.

\section{Discussion}

Flooding can result to anaerobic stress that can eventually lead to yield loss. Rice is considered the most

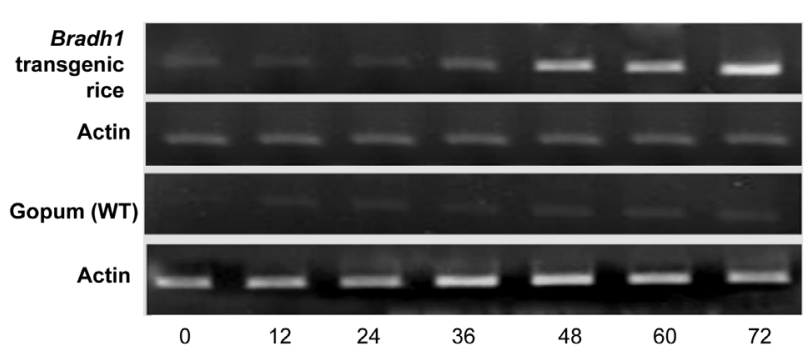

Fig. 9 Expression of Bradh1 gene in transgenic rice plants and wild type, Gopumbyeo under anoxia conditions. Upper panel shows $m$ RNA expression level of Bradhl gene under anaerobic stress at different time intervals $(0,12,24,36,48,60,72 \mathrm{~h})$ and lower panel shows internal actin used for loading adjustment

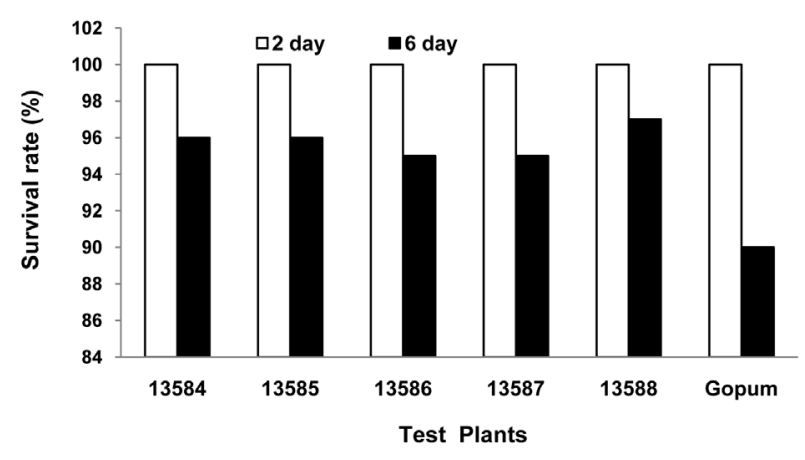

Fig. 10 Ability of transgenic rice and Gopumbyeo seedlings to survive after a subsequent period of anaerobiosis

flooding tolerant plant, but it can only survive up to a certain point. Alcohol dehydrogenase is considered essential for anoxia survival because it recycles $\mathrm{NAD}^{+}$for continued glycolysis in the absence of oxygen (Roberts et al. 1984; Johnson et al. 1994). adh1 has been cloned and well studied in several crops (Chang et al. 1986; Gottlieb 1982). However, adh1 in Chinese cabbage has not been explored. In this study, Bradhl from Chinese cabbage was cloned and subsequently transformed into rice. In the sequence analysis, Bradh1 contains an open reading frame of $1,140 \mathrm{bp}$ similar to the other adh1 capable of encoding a polypeptide the same length as maize and having $80 \%$ homology with both maize enzymes (Chang and Meyerowitz 1986). Also, Boadl1 showed high nucleotide similarities with Bradh1 (Fig. 2). This high similarity is reflected in the phylogenic tree analysis where Atadh1, Boadh1 and Bradh1 clade in the same group (Fig. 3). Other related species, Osadh1 (Japonica), Zmadh1, and Osadh1 (indica) form other clade. The high sequence similarity usually implies significant functional or structural similarity.

Transgenic rice lines inserted with alcohol dehydrogenase gene from Brassica rapa were developed through Agrobacterium-mediated transformation with high efficiency. 
$\mathrm{T}_{1}$ generations with the Bradhl full-length cDNA and hygromycin phosphotransferase marker gene were successfully integrated into the rice Gopumbyeo.

Expression level of Bradh1 mRNA transcript was assayed to be higher than the wild type, Gopumbyeo, and highly expressed in seedling, root, and seed (Fig. $5,6)$. This result was similar to the findings in maize by Freeling and Bennett (1985), and in Arabidopsis by Dolferus et al. (2003). The ADH enzyme is therefore regulated at the transcriptional level (Xie and Wu 1989; Lasanthi-Kudahettige et al. 2007). It is not brought about by the conversion of an inactive $\mathrm{ADH}$ into an active enzyme (Kadowaki et al. 1988), or by the decline of the inactivator activity itself (Shimomura and Beevers 1983).

The ADH activity for both transgenic rice lines and wild type was both increasing as the length of anaerobic induction increases (Fig. 7, 8). This ADH induction is reflected to the enhanced mRNA gene expression (Fig. 9), higher seedling survival (Fig. 10) compared to the wild type. Collectively, these results clearly demonstrated that the transgenic rice lines transformed with a full-length cDNA of alcohol dehydrogenase (Bradhl) showed overexpression compared to wild type, Gopumbyeo. Overexpression of Bradhl will be useful for future development of rice varieties that are flood-tolerant or can be planted through direct seeding. It will also be very informative for further functional gene analysis.

\section{Acknowledgement}

This work was supported by the research grant of the Chungbuk National University in 2009.

\section{References}

Alpi A, Beevers $\mathrm{H}$ (1983) Effects of $\mathrm{O}_{2}$ concentration on rice seedlings. Plant Physiol 7:30-34

Armstrong W, Brandle R, Jackson MB (1994) Mechanisms of flood tolerance in plants. Acta Bot Neeri 43:307-358.

Aspart L, Got A, Delseny M, Mocquot B, Pradet A (1983) Adaptation of ribonucleic acid metabolism to anoxia in rice embryos. Plant Physiol 7:115-121

Atwell BJ, Waters I, Greenway H (1982) The effect of oxygen and turbulence on elongation of coleoptiles of submergencetolerant and intolerant cultivars. J Exp Bot 33:1030-1044

Battraw MJ, Hall TC (1992) Expression of a chimeric neomycin phosphotransferase II gene in first and second generation transgenic rice plants. Plant Sci 86:191-202

Chan MT, Chang HH, Ho SL, Tong WF, Yu SM (1993) Agrobacterium-mediated production of transgenic rice plants expressing a chimeric $\alpha$-amylase promoter $/ \beta$-glucuronidase gene. Plant Mol Biol 22:491-506

Chang C, Meyerowitz EM (1986) Molecular cloning and DNA sequence of the Arabidopsis thaliana alcohol dehydrogenase gene. Proc Natl Acad Sci USA 83:1408-1412

Cho YG, Kang HJ, Lee JS, Lee YT, Lim SJ, Gauch H, Eun MY, McCouch SR (2007) Identification of quantitative trait loci in rice for yield, yield components, and agronomic traits across years and locations. Crop Sci 47:2403-2417

Christou P, Ford TL, Kofron M (1991) Production of transgenic rice (Oryza sativa L.) plants from agronomically important indica and japonica varieties via electric discharge particle acceleration of exogenous DNA into immature zygotic embryos. Bio Technology 9:957-962

Chung H-J, Ferl RJ (1999) Arabidopsis alcohol dehydrogenase expression in both shoots and roots is conditioned by root growth environment. Plant Physiol 121:429-436

Cobb BG, Kennedy RA (1987) Distribution of alcohol dehydrogenase in roots and shoots of rice (Oryza sativa) and Echinochloa seedlings. Plant Cell Environ 10:633-638

Colmer TD (2003) Long-distance transport of gases in plants: a perspective on internal aeration and radial oxygen loss from roots. Plant Cell Environ 26:17-36

Crawford R MM (1992) Oxygen availability as an ecological limit to plant distribution. Adv Ecol Res 23:93-185

Datta SK, Peterhans A, Datta K, Potrykus I (1990) Genetically engineered fertile indica rice recovered from protoplasts. Bio Technology 8:736-740

Davey MR, Kothari SL, Zhang H, Rech EL, Cocking EC, Lynch PT (1991) Transgenic rice: characterization of protoplast-derived plants and their seed progeny. J Exp Bot 42:1159-1169

Dennis ES, Dolferus R, Ellis M, Rahman M, Wu Y, Hoeren FU, Grover A, Ismond KP, Good AG, Peacock WJ (2000) Molecular strategies for improving waterlogging tolerance in plants. J Exp Bot 51:89-97

Dolferus R, Klok EJ, Delessert C, Wilson S, Ismond KP, Good AG, Peacock WJ, Dennis ES (2003) Enhancing the anaerobic response. Ann Bot 91:111-117

Drew MC (1997) Oxygen deficiency and root metabolism: injury and acclimation under hypoxia and anoxia. Annu Rev Plant Physiol Plant Mol Biol 48:223-250

Drew MC, He CJ, Morgan PW (2000) Programmed cell death and aerenchyma formation in roots. Trends Plant Sci 5: $123-127$

Freeling M, Bennett DC (1985) Maize Adh1. Ann Rev Genet 19:297-323

Gibbs J, Greenway H (2003) Mechanisms of anoxia tolerance in plants. I. Growth, survival and anaerobic catabolism. Funct Plant Biol 30:41-47

Grichko VP and Glick BR (2001) Flooding tolerance of transgenic tomato plants expressing the bacterial enzyme ACC deaminase controlled by the $35 \mathrm{~S}$, rolD or PRB- $1 b$ promoter. Plant Physiol Biochem 39:19-25

Gottlieb LD (1982) Conservation and duplication of isozymes 
in plants. Science 216:373-380

Hansen G (2000) Evidence for Agrobacterium-induced apoptosis in maize cells. Mol Plant-Microbe Interact 13:649-657

Hensel G, Valkov V, Middlefell-Williams J, Kumlehn J (2008) Efficient generation of transgenic barley: the way forward to modulate plant-microbe interactions. J Plant Physiol 165:71-82

Hiei Y, Ohta S, Komari T, Kumashiro T (1994) Efficient transformation of rice (Oryza sativa L.) mediated by Agrobacterium and sequence analysis of the boundaries of the T-DNA. Plant J 6:271-282

Ishida Y, Saito H, Oita S, Hiei Y, Komari T, Kumashito T (1996) High efficiency transformation of maize (Zea mays L.) mediated by Agrobacterium tumefaciens. Nat Biotechnol $14: 745-750$

Jackson MB (1985) Ethylene and the responses of plants to soil water-logging and submergence. Annu Rev Plant Physiol 36:145-174

Jeon JS, Lee S, Jung KH (2000) T-DNA insertional mutagenesis for functional genomics in rice. Plant J 22:561-570

Johnson JR, Cobb BG, Drew MC (1994) Hypoxic induction of anoxia tolerance in roots of Adh1 null Zea mays L. Plant Physiol 105:61-67

Kadowaki KI, Matsuoka M, Murai N, Harada K (1988) Induction of two alcohol dehydrogenase polypeptides in rice roots during anaerobiosis. Plant Science. 54:29-36.

Kennedy RA, Rumpho ME, Fox TC (1992) Anaerobic metabolism in plants. Plant Physiol 84:1204-1209

Kordan HA (1977) Coleoptile emergence in rice seedlings in different oxygen environments. Annals of Botany 41:12051209

Lasanthi-Kudahettige R, Magneschi L, Loreti E, Gonzali S, Licausi F, Giacomo N, Berreta O, Federico V, Alpi A, Perata P (2007) Transcript profiling of the anoxic rice coleoptile. Plant Physiol 144:218-231.

Lee S, Jeon JS, Jung KH, An G (1999) Binary vector for efficient transformation of rice. J Plant Biol 42:310-316

Li Z, Burow MD, Murai N (1990) High frequency generation of fertile transgenic rice plants after PEG-mediated protoplast transformation. Plant Mol Biol Rep 8:276-291

Liao CT, Lin CL (2001) Physiological adaptation of crop plants to flooding stress. Proc Natl Sci Counc Repub China B 25:148-157

Mergemann H, Sauter M (2000) Ethylene induces epidermal cell death at the site of adventitious root emergence in rice. Plant Physiol 124:609-614

Mooney PA, Goodwin PB, Dennis ES, Liewellyn DJ (1991) Agrobacterium tumefaciens-gene transfer into wheat tissues. Plant Cell Tissue Organ Cult 25:209-218

Mujer CV, Rumpho ME, Lin JJ, Kennedy RA (1993) Constitutive and inducible aerobic and anaerobic stress proteins in the Echinochloa complex and rice. Plant Physiol 101:217-226

Mocquot B, Prat C, Mouches C, Pradet A (1981) Effect of anoxia on energy charge and protein synthesis in rice embryo. Plant Phy.siology 68:636-640

Narashimulu SB, Deng XB, Sarria R, Gelvin SB (1996) Early transcription of Agrobacterium T-DNA genes in tobacco and maize. Plant Cell 8:873-886

Pathuri IP, Reitberger IE, Hückelhoven R, Proels RK (2011) Alcohol dehydrogenase 1 of barley modulates susceptibility to the parasitic fungus Blumeria graminis f.sp. hordei. J Exp Bot in press

Perata P, Gugloelminetti L, Alpi A (1997) Mobilization of endorsperm reserves in cereal seeds under anoxia. Ann Bot 79:49-56

Quimio CA, Torrizo LB, Setter TL, Ellis M, Grover A, Abrigo EM, Oliva NP, Ella ES, Carpena AL, Ito O et al. (2000) Enhancement of submergence tolerance in transgenic rice overproducing pyruvate decarboxylase. J Plant Physiol 156:516-521

Raineri DM, Bonitto P, Gordon MP, Nester EW (1990) Agrobacterium-mediated transformation in rice (Oryza sativa L.). Bio Technology 8:33-38

Ricard B, Mocquot B, Fournier A, Delseny M, Pradet A (1986) Expression of alcohol dehydrogenase in rice embryos under anoxia. Plant Mol Bio 7:321-329

Ritchie SW, Lui CHN, Sellmer JC, Kononowicz H, Hodges TK, Gelvin SB (1993) Agrobacterium tumefaciens-mediated expression of gusA in maize tissues. Trans Res 2:252-265

Roberts JKM, Callis J, Wemmer D, Walbot V, Jardetzky O (1984) Mechanism of cytosolic $\mathrm{pH}$ regulation in hypoxic maize root tips and its role in survival under anoxia. Proc Nat Acad Sci USA 81:33791-3383

Sallaud C, Meynard D, Boxtel JV (2003) Highly efficient production and characterization of T-DNA plants for rice (Oryza sativa L.) functional genomics. Theor Appl Genet 106:1396-1408

Sauter M (2000) Rice in deep water: How to take heed against a sea of troubles. Naturwissenschaften. 87:289-303

Setter TL, Ellis M, Laureles EV, Ella ES, Senadhira D, Mishra SB, Sarkarung S, Datta S (1997) Physiology and genetics of submergence tolerance in in rice. Ann Bot 79:67-77

Shimamoto K, Terada R, Izawa T, Fujimoto H (1989) Fertile transgenic rice plants regenerated from transformed protoplasts. Nature 238:274-276

Shimomura S, Beevers H (1983) Alcohol dehydrogenase and an inactivator from rice seedlings. Plant Physiol 71:736741

Tai HT, Tanksley SD (1990) A rapid and inexpensive method for isolation of total DNA from dehydrated plant tissue. Plant Mol Bio Reporter 8:297-303

Takahaski N (1978) Adaptive importance of mesocotyl and coleopile growth in rice under different moisture regimes. Australian J Pant Physiol 5:511-517

Tingay S, McElroy D, Kalla R, Fieg S, Wang M, Thornton S, Brettel R (1997) Agrobacterium tumefaciens-mediated barley transformation. Plant J 11:1369-1376

Toki S, Hara N, Ono K, Onodera H, Tagiri A, Oka S, Tanaka H (2006) Early infection of scutellum tissue with Agro- 
bacterium allows high-speed transformation of rice. Plant J 47:969-976

Thompson C, Fernandes C, De Souza O, De Freitas L, Salzano F (2010) Evaluation of the impact of functional diversification on Poaceae, Brassicaceae, Fabaceae, and Pinaceae alcohol dehydrogenase enzymes. J Mol Modeling 16:919928

Turner F, Chen TC, McCauly GN (1981) Morphological development of rice seedling in water at controlled oxygen levels. Agronomy J 73:566-570

Uze M, Wunn J, Puonti-Kaerlas J, Potrykus I, Sautter C (1997) Plasmolysis of precultured immature embryos improves Agrobacterium mediated gene transfer to rice (Oryza sativa L.). Plant Sci 130:87-95

Vartepetian BB, Mazlik P, Lance C (1978) Lipid biosynthesis in rice coleoptiles grown in the presence or in the absence of oxygen. Plant Sci Lett 13:321-328

Vartapetian BB, Jackson MB (1997) Plant adaptations to anaerobic stress. Ann Bot 79:3-20

Voesenek LACJ, Benschop JJ, Bou J, Cox MCH, Groeneveld HW, Millenaar FF, Vreeburg RAM, Peeters AJM (2003) Interactions between plant hormones regulate submergenceinduced shoot elongation in the flooding-tolerant dicot Rumex palustris. Ann Bot 91:205-211

Voesenek LACJ, Colmer TD, Pierik R, Millenaar FF, Peters AJM (2006) How plants cope with complete submergence. New Phytol 170:213-226

Xie Y, Wu R (1989) Rice alcohol dehydrogenase genes: anaerobic induction, organ specific expression and characterization of cDNA clones. Plant Mol Bio 13:53-68

Xu Y, Buchholz WG, DeRose RT, Hall TC (1995) Characterization of a novel gene family from rice that encodes root-specific proteins. Plant Mol Biol 27:237-248

Zhang J, Van Toai T, Huynh L, Preiszner J (2000) Development of flooding tolerant Arabidopsis thaliana by autoregulated cytokinin production. Mol Breed 6:135-144 